\title{
Characterization of polyphenol oxidase in two cocoa (Theobroma cacao L.) cultivars produced in the south of Bahia, Brazil
}

\author{
Adrielle Souza Leão MACEDO $^{1}$, Fátima de Souza ROCHA ${ }^{1}$, Margareth da Silva RIBEIRO ${ }^{1}$, \\ Sergio Eduardo SOARES ${ }^{1 \star}$, Eliete da Silva $\mathrm{BISPO}^{1}$
}

\begin{abstract}
The reactions leading to the formation of precursors of chocolate flavor are performed by endogenous enzymes present in the cocoa seed. Polyphenol oxidase (PPO) presence and activity during fermentation of cocoa beans is responsible for the development of flavor precursors and is also implicated in the reduction of bitterness and astringency. However, the reliability of cocoa enzyme activities is complicated due to variations in different genotypes, geographical origins and methods of fermentation. In addition, there is still a lack of systematic studies comparing different cocoa cultivars. So, the present study was designed to characterize the activity of PPO in the pulp and seeds of two cocoa cultivars, PH 16 and TSH 1188. The PPO activity was determined spectrophotometrically and characterized as the optimal substrate concentration, $\mathrm{pH}$ and temperature and the results were correlated with the conditions during the fermentation process. The results showed the specificity and differences between the two cocoa cultivars and between the pulp and seeds of each cultivar. It is suggested that specific criteria must be adopted for each cultivar, based on the optimal PPO parameters, to prolong the period of maximum PPO activity during fermentation, contributing to the improvement of the quality of cocoa beans.
\end{abstract}

Keywords: cocoa; fermentation; enzyme activity; chocolate.

Practical Application: To obtain knowledge for future technological interventions during fermentation for the improvement of the quality of raw material in the production of monovarietal chocolates.

\section{Introduction}

The reactions leading to the formation of precursors of chocolate flavor are performed by endogenous enzymes present in the cocoa seed. A main consequence of the fermentation process is the lowering of $\mathrm{pH}$, favoring the action of those enzymes. During fermentation, the pulp covering cocoa seeds is degraded by the successive action of microorganisms (yeasts and lactic acid and acetic acid bacteria) natural to the environment, accompanied by increases of temperature to approximately $50^{\circ} \mathrm{C}$ (Cruz et al., 2013).

The enzyme activity in cocoa beans during fermentation has been known and studied at least since the second half of the 20th century. It is currently believed that the enzymes polyphenol oxidase, invertase and protease have a central importance in the formation of chocolate flavor (Hansen et al., 1998). Polyphenol oxidase (PPO) is widely distributed in nature and is responsible for the catalysis of oxidation reactions of phenols in the presence of oxygen, the products of which polymerize, forming dark-colored compounds (Robinson \& Eskin, 1991a, b). PPO presence and activity during fermentation and drying of cocoa beans is responsible for the development of flavor precursors, starting during the oxidation phase of fermentation and continuing during drying (Lima et al., 2001). PPO activity is also implicated in the reduction of bitterness and astringency of cocoa flavor (Reeves et al., 1988).

The reliability and comparison of cocoa enzyme activities is complicated due to variations to different genotypes, geographical origins, methods of fermentation and type of fermentation vats used. Although the essential role of endogenous enzymes during fermentation has been known for many years, there is still a lack of systematic studies comparing different cocoa cultivars (Hansen et al., 1998). In addition, the regulation of enzymatic processes during fermentation, which enzymatic substrates/products are related to the flavor of cocoa beans of superior quality and which are the limiting factors for these processes (substrate and/or enzyme availability, genotype, growth conditions or fermentation process) are still not known.

The goal of the present study was to characterize the activity of PPO in two cocoa cultivars produced in the southern region of Bahia and to relate it to the conditions during the fermentation process to obtain knowledge for future technological interventions for the improvement of the quality of raw material in the production of monovarietal chocolates.

\section{Materials and methods}

\subsection{Materials}

Two cocoa cultivars, PH 16 and TSH 1188, produced at the Lajedo do Ouro farm, city of Ibirataia, in the southern region of the state of Bahia (BA), Brazil, were tested. The two cultivars were chosen by the producers based on their availability at 
the period of performance of the experiment. Cultivar PH 16 (a Forastero hybrid resulting from the crossing between cultivars Forastero do Alto Amazônico and Trinitario) was identified in 1996 from a population of hybrid cocoa plants at the Porto Híbrido Farm, municipality of São José da Vitória, BA. Cultivar TSH 1188 (Trinidad Selected Hybrids, a trinitarian hybrid), originates from Trinidad and Tobago, located close to the west coast of Venezuela, and presents resistance to witches' broom disease and excellent productivity.

\subsection{Fermentation}

Fermentation was performed in wooden fermentation vats $(70 \mathrm{~cm} \times 70 \mathrm{~cm} \times 75 \mathrm{~cm})$, with capacity for $400 \mathrm{~kg}$ cocoa mass, with approximately 20 holes $(1.27 \mathrm{~cm}$ each) at the bottom and lateral walls to drain the cocoa honey produced by the pulp during fermentation. The fermentation lasted seven days, during which the cocoa mass was turned every 48 hours to oxygenate the mass and homogenize the temperature. The cocoa mass was covered with banana leaves.

\subsection{Sample collection}

Samples were collected before the beginning of fermentation (time zero) and then every 12 hours until the end of the fermentation. The temperature (Digital Thermometer MINIPA MT - 450) and pH (Portable pHmeter PHtek Digital) of the cocoa mass were measured during fermentation (Horwitz, 2000).

\subsection{Characterization of $P P O$}

Enzyme activity was determined from the pulp and seed of the two cocoa cultivars tested before the beginning of fermentation (time zero). Effects of temperature and $\mathrm{pH}$ on the enzyme activity and the enzyme's preferential substrate were tested. The results obtained for the enzyme's optimal temperature and $\mathrm{pH}$ were compared to the temperatures and $\mathrm{pH}$ measured during fermentation, with the goal of identifying the stage of the fermentation process when the conditions are more favorable for PPO activity.

\section{Extraction of pulp PPO}

Enzymes were extracted in accordance with Lima et al. (2001) using 100 g cocoa seed. Pulp was manually separated from the seeds and immersed in $0.02 \mathrm{M}$ potassium phosphate buffer, $\mathrm{pH} 7.5$, with $5 \%$ polyethylene glycol and $5 \mathrm{mM}$ ascorbic acid. The material was then ground in the same buffer solution, in a $1: 2(\mathrm{w} / \mathrm{v})$ ratio, and homogenized for 30 minutes at $4{ }^{\circ} \mathrm{C}$. The homogenate was centrifuged at 11,000 $\mathrm{xg}$ for 15 minutes at $0{ }^{\circ} \mathrm{C}$, using a refrigerated centrifuge HITACHI CR22GIII. The supernatant (extract) was stored at $-18^{\circ} \mathrm{C}$ until analyzed.

\section{Extraction of seed $P P O$}

Enzymes were extracted in accordance with Lima et al. (2001). The seeds were freeze-dried (freeze-dryer Liotop L108) and degreased using petroleum ether as solvent (Yusep et al., 2002). Dry and degreased seeds were suspended on $0.02 \mathrm{M}$ potassium phosphate buffer, $\mathrm{pH} 7.5$, with $5 \%$ polyethylene glycol and $5 \mathrm{mM}$ ascorbic acid, in a 1:10 (w/v) ratio, and homogenized using a magnetic shaker for 30 minutes at $4{ }^{\circ} \mathrm{C}$. The suspension was centrifuged at $11,000 \mathrm{xg}$ for 15 minutes at $0^{\circ} \mathrm{C}$. The supernatant (extract) was stored at $-18^{\circ} \mathrm{C}$ until analyzed.

\section{Purification of extracted $P P O$}

The enzyme was purified in accordance with Erzengin (2009). Ammonium sulfate $\left[\left(\mathrm{NH}^{4}\right)_{2} \mathrm{SO}_{4}\right]$ was added to the extracts in sufficient quantity to reach $80 \%$ saturation. The salt was added slowly, with gentle stirring, at $4{ }^{\circ} \mathrm{C}$, and the resulting mix was centrifuged at $20,000 \mathrm{xg}$ for 60 minutes at $4{ }^{\circ} \mathrm{C}$; the pellet was set aside. The pellet was resuspended in $0.02 \mathrm{M}$ potassium phosphate buffer, $\mathrm{pH} 6.5$, and dialyzed in the same buffer using acetate membranes for 24 hours at $4{ }^{\circ} \mathrm{C}$. Following dialysis, the protein fraction was precipitated with ketone in a $2: 1(\mathrm{v} / \mathrm{v})$ ratio and separated through centrifugation at $11,000 \mathrm{xg}$ for 15 minutes at $0{ }^{\circ} \mathrm{C}$. The pellet was resuspended in $0.02 \mathrm{M}$ potassium phosphate buffer, $\mathrm{pH} 6.5$, and stored at $-18{ }^{\circ} \mathrm{C}$ for performance of the remaining analyses (Perone et al., 2007).

\section{Determination of extracted $P P O$ activity}

he enzyme activity was determined spectrophotometrically (Biochrom Libra S50) by measuring the increase in absorbance at $420 \mathrm{~nm}$ for the substrate (catechol) at concentrations between $0.05 \mathrm{M}$ and $0.4 \mathrm{M}$. The reaction mix consisted of $2.5 \mathrm{~mL}$ of $0.2 \mathrm{M}$ sodium phosphate buffer, $\mathrm{pH} 7.0,0.3 \mathrm{~mL}$ catechol at the different concentrations tested and $0.2 \mathrm{~mL}$ extract containing the enzyme in a $3.0 \mathrm{~mL}$ final volume. A blank was used, consisting of $0.3 \mathrm{~mL}$ substrate and $2.7 \mathrm{~mL}$ of $0.2 \mathrm{M}$ sodium phosphate buffer, $\mathrm{pH} 7.0$, to which no extract was added. The temperature was kept constant at $25^{\circ} \mathrm{C}$. The enzyme activity was calculated considering the linear zone of the activity curve. One unit of PPO activity $(\mathrm{U})$ was defined as the quantity of enzyme causing a $0.001 . \mathrm{mL}^{-1} \cdot \mathrm{min}^{-1}$ increase in absorbance (Erzengin, 2009).

\section{Determination of the kinetic parameters of PPO Km and Vmax}

$\mathrm{Km}$ and Vmax were determined for different concentrations of catechol $(0.05 \mathrm{M}$ to $0.4 \mathrm{M})$. The data were presented graphically as $1 / \mathrm{V}_{0}$ and $1 /[\mathrm{S}]$ in accordance with LINEWEVER-BURK's method (Lineweaver \& Burk, 1934).

\section{Effect of $\mathrm{pH}$ and temperature on $\mathrm{PPO}$ activity}

The optimal $\mathrm{pH}$ and temperatures of the reaction were determined using the same method described above for the measurement of enzymatic activity; the tested $\mathrm{pH}$ levels were $2,3,4,5,6,7$ and 8 , and the tested temperatures were 20,25 , $30,40,50$ and $60^{\circ} \mathrm{C}$.

\section{Determination of the enzyme's preferential substrate}

The enzyme activity was determined as described above, at the previously determined optimal $\mathrm{pH}$ and temperature, using $(+)$-catechin and (-)-epicatechin (the main phenols present at cocoa) as substrates (Efraim et al., 2011). 
Correlation between fermentation parameters and the extractable enzyme activity

To evaluate the PPO behavior during fermentation, PPO activities measured in pulp and seed extracts of the tested cultivars at time zero were compared with the $\mathrm{pH}$ and temperatures measured during fermentation.

\subsection{Determination of the protein concentration in extracts}

The protein concentrations in the extracts were determined in accordance with Lowry et al. (1951) and used in the calculation of specific enzyme activities.

\subsection{Statistical analysis}

Six replicates were performed for all the analyses, and the standard deviation was determined.

\section{Results and discussion}

\subsection{Determination of the extractable PPO activity}

Large differences in enzyme activity were observed between the pulps of the two cultivars tested (Figure 1a). The PPO activity was approximately 6 times higher for cultivar TSH 1188 than for cultivar PH 16, indicating a higher presence of PPO in cultivar TSH 1188. This higher enzyme activity will very likely have an effect on phenol concentration and behavior during and following fermentation because PPO strongly acts on phenols during the aerobic phase of fermentation, converting them into quinones (Misnawi et al., 2002). This process may result in changes of sensory characteristics, such as flavor and color (Misnawi et al., 2003). PPO activity was lower in the seeds than in the pulp (Figure 1b), and the activity was similar in the seeds of both of the cultivars. However, the difference between the PPO activities of pulp and seeds were larger for cultivar TSH 1188 than for cultivar PH 16.
The differences in PPO activity observed between cultivars were reflected in the enzyme's kinetic parameters (Figure 2). PPO presented good affinity for catechol, as indicated by the low $\mathrm{Km}$ values. In the pulp, a Km of $0.107 \mathrm{mg} \cdot \mathrm{mL}^{-1}$ and $\mathrm{Vmax}$ of $10.6 \mathrm{mg} . \mathrm{mL} \mathrm{min}^{-1}$ were observed for cultivar PH 16, whereas for cultivar TSH 1188, a Km of $0.089 \mathrm{mg} \cdot \mathrm{mL}^{-1}$ and a Vmax of

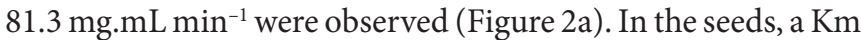
of $0.047 \mathrm{mg} \cdot \mathrm{mL}^{-1}$ and a Vmax of $2.3 \mathrm{mg} \cdot \mathrm{mL} \mathrm{min}^{-1}$ were observed for PH 16, and a Km of $0.02 \mathrm{mg} \cdot \mathrm{mL}^{-1}$ and a Vmax of $2.3 \mathrm{mg} \cdot \mathrm{mL}$ $\mathrm{min}^{-1}$ were observed for TSH 1188 (Figure 2b).

The PPO affinity for different substrates and substrate concentrations depends not only on the origin of the enzyme (type of plant) (Oktay et al., 1995) but also on the plant species and cultivar.

\subsection{Effect of pH on PPO activity}

Although higher activities were observed with higher catechol concentrations (Figure $1 \mathrm{a}, \mathrm{b}$ ), the $0.1 \mathrm{M}$ concentration was chosen for PPO assays for both pulp and seed because the PPO behavior was similar for both of the cultivars at that concentration and because of the low deviation obtained at that concentration.

The optimal $\mathrm{pH}$ for PPO activity from cocoa pulp and seeds were determined by testing the enzyme activity at $\mathrm{pH}$ values between 2 and 8 at $25^{\circ} \mathrm{C}$ constant temperature with $0.1 \mathrm{M}$ catechol as substrate. For cultivar $\mathrm{PH} \mathrm{16}$, the optimal $\mathrm{pH}$ for pulp extracts was 6.5 , and for seed extracts, the optimal $\mathrm{pH}$ was 5.8, with enzyme activities 7.1 U.mg protein ${ }^{-1}$ and $6.5 \mathrm{U}$. mg protein $^{-1}$, respectively (Figure 3a).

For cultivar TSH 1188, the optimal $\mathrm{pH}$ for pulp extracts was 6.6 and for seed extracts was 6.0 (Figure 3b). As previously described, the enzyme activity was much higher in the pulp than in the seeds, with 43.1 U.mg protein ${ }^{-1}$ and 4.3 U.mg protein ${ }^{-1}$, respectively. This pattern might basic $\mathrm{pH}$ levels, with 70 to $90 \%$
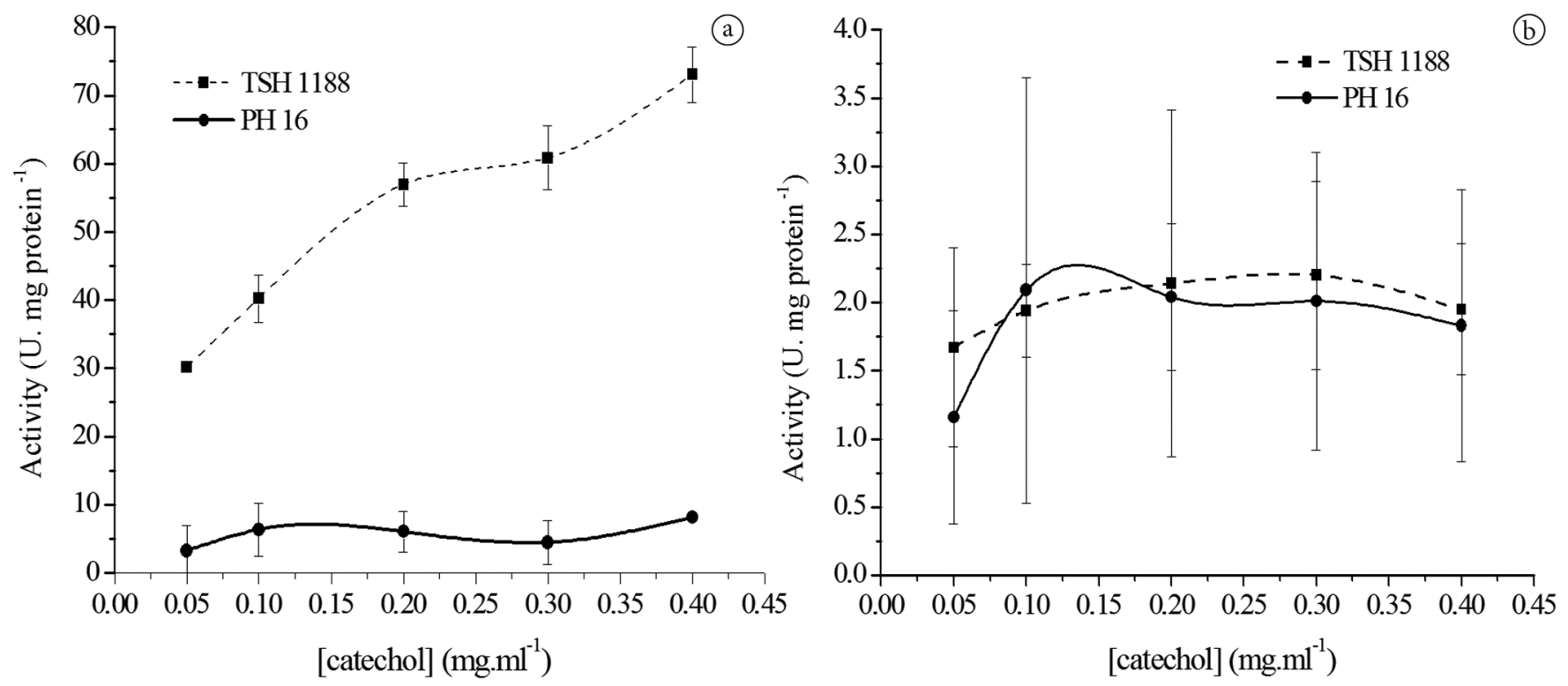

Figure 1. PPO activity as a function of substrate (catechol) concentration (0.05 M to 0.4 M). (a) Pulp; (b) Seed. 

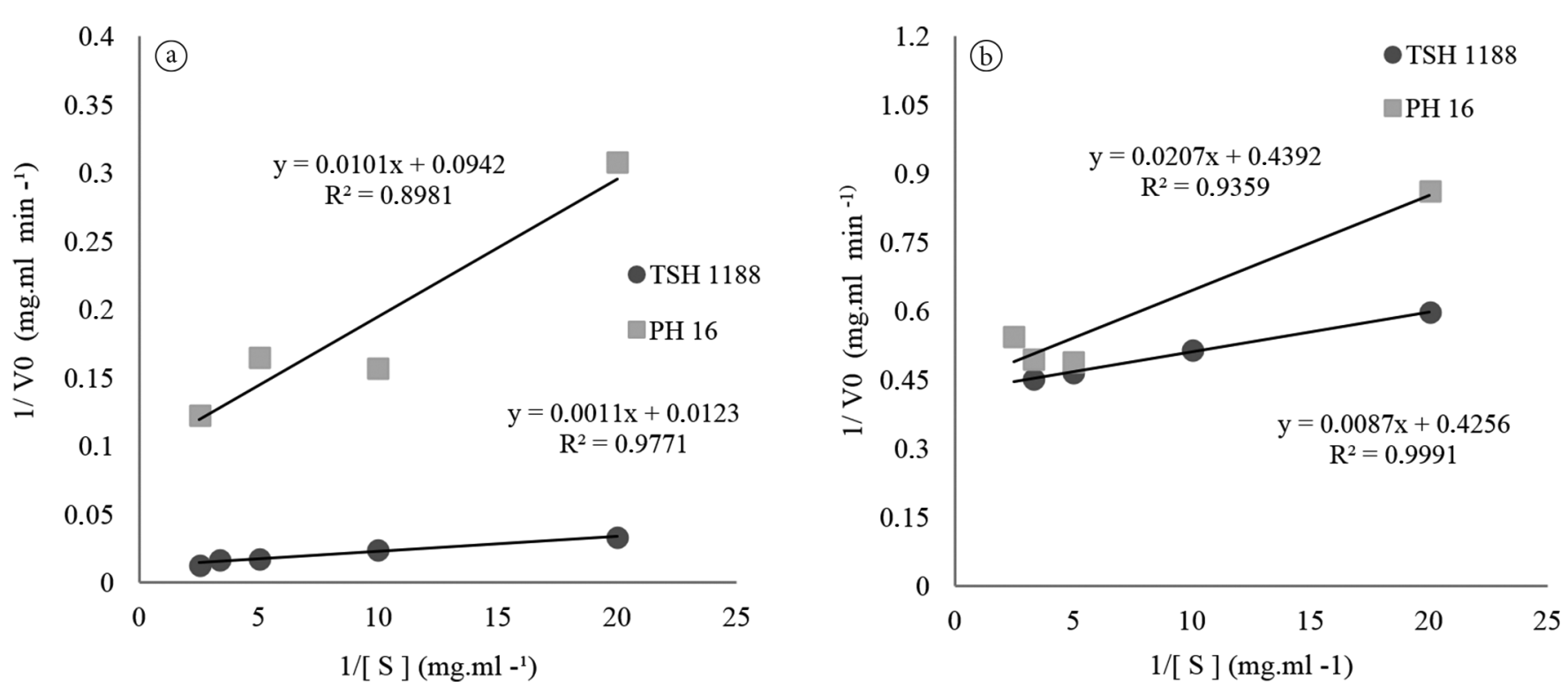

Figure 2. LINEWEVER-BURK plots showing the dependence of PPO activity on substrate (catechol) concentration for the two tested cocoa cultivars. (a) Pulp; (b) Seed.
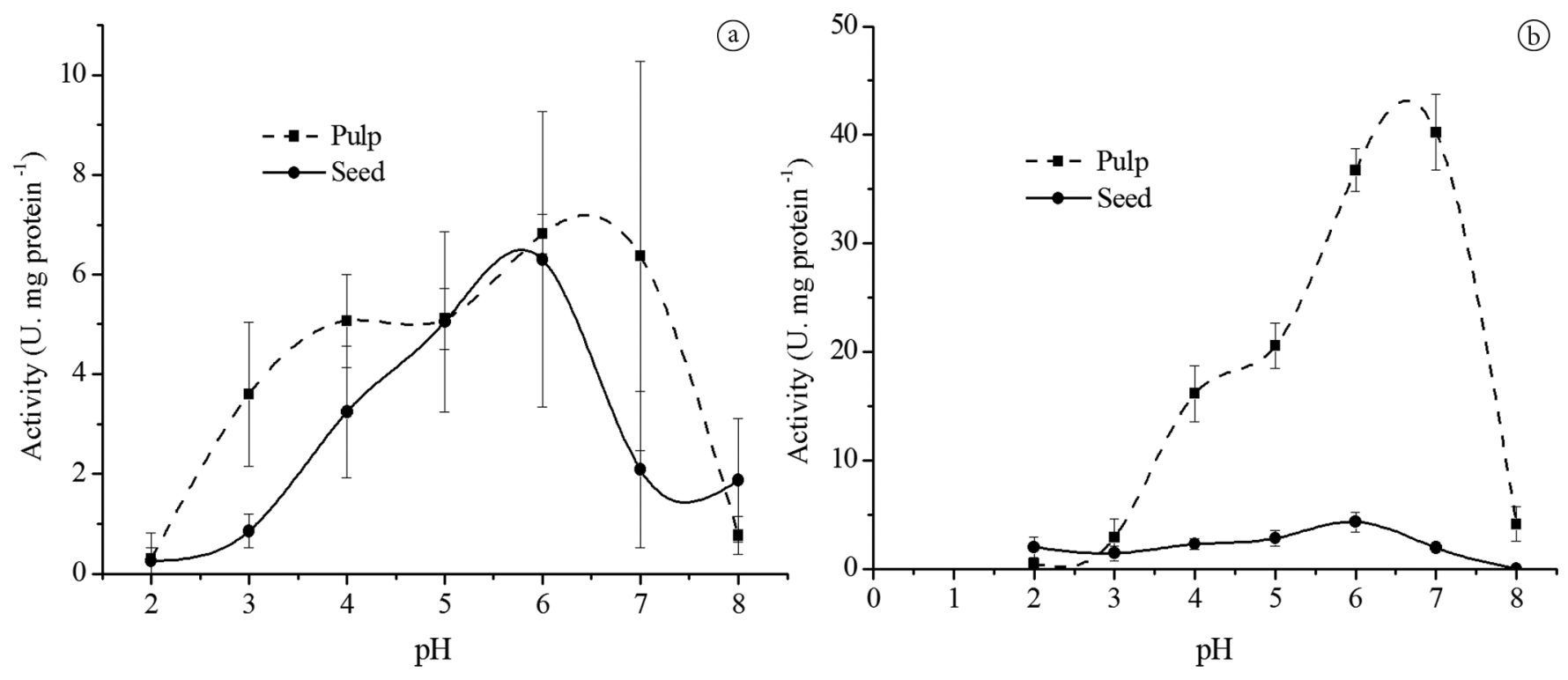

Figure 3. pH dependence of PPO activity. (a) Cultivar PH 16; (b) Cultivar TSH 1188.

loss in potential activity. Similar observations were reported occur because the optimal $\mathrm{pH}$ for PPO activity varies with the extraction method, type of substrate and enzyme location in the plant cell (Dogan et al., 2005). For cultivar PH 16, the activities of the pulp and seed extracts presented similar behaviors.

For the tested cultivars, the PPO activity was low at low $\mathrm{pH}$ and pronouncedly decreased at by Toralles et al. (2010) for peaches, for which the optimal $\mathrm{pH}$ for PPO varied between 6.0 and 7.5, depending on the substrate and plant tissue. Below this $\mathrm{pH}$ range, the enzyme was less active, and above this $\mathrm{pH}$ range, substrate auto-oxidation took place.

\subsection{Effect of temperature on PPO activity}

The optimal temperatures for PPO activity from cocoa pulp and seeds were determined by testing enzyme activities at a temperature range from 20 to $60{ }^{\circ} \mathrm{C}$, at the previously determined optimal $\mathrm{pH}$ values (TSH 1188: 6.6 for pulp and 6.0 for seed; PH 16: 6.5 for pulp and 5.8 for seed), with $0.1 \mathrm{M}$ catechol as substrate. For PH 16, maximal PPO activity was reached at $30^{\circ} \mathrm{C}$ for the seed (9.7 U.mg protein ${ }^{-1}$ ) and at $27^{\circ} \mathrm{C}$ for the pulp (7.1 U.mg protein ${ }^{-1}$ ) (Figure 4a). For cultivar TSH 1188, the optimal temperature was $25{ }^{\circ} \mathrm{C}$, with $4.3 \mathrm{U} . \mathrm{mg}$ protein ${ }^{-1}$ enzyme activity for the seed and 40.3 U.mg protein ${ }^{-1}$ for the 

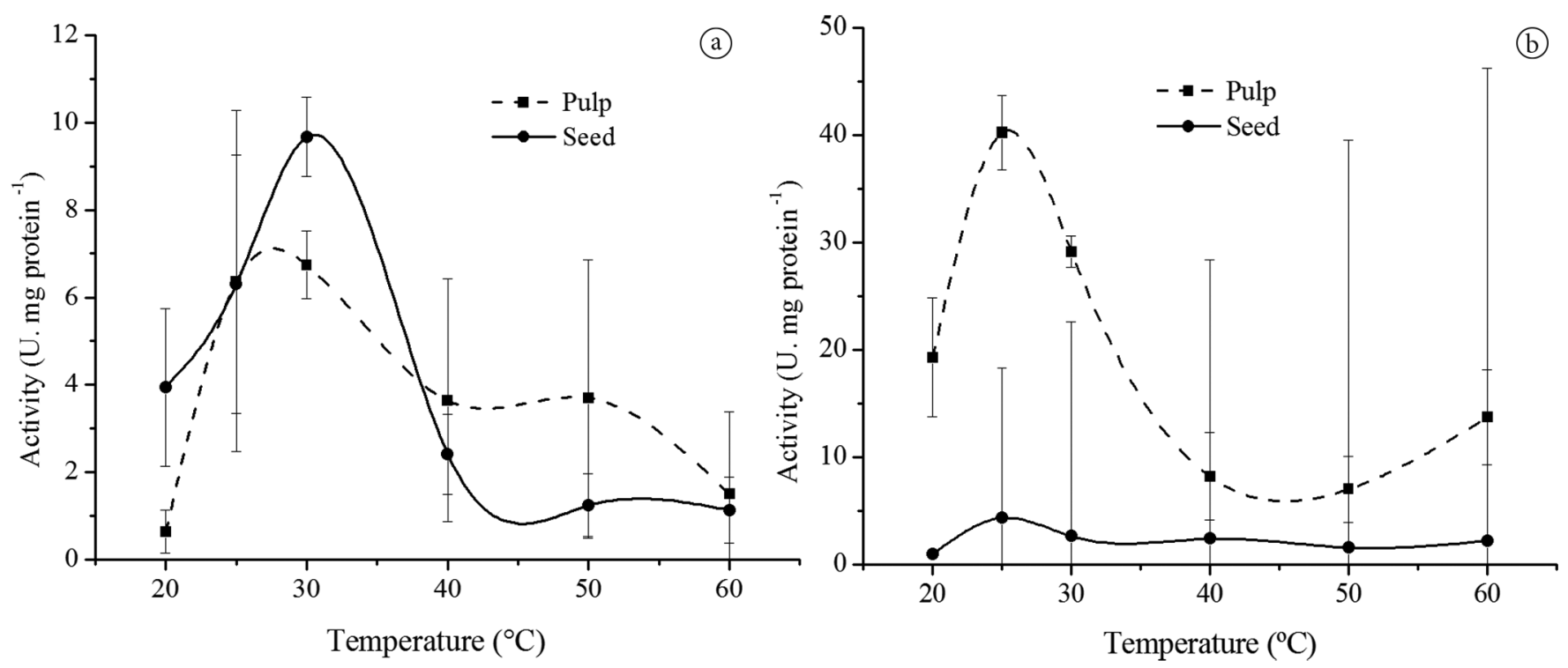

Figure 4. Temperature effect on PPO activity. (a) Cultivar PH 16; (b) Cultivar TSH 1188.

pulp (Figure $4 \mathrm{~b}$ ). The drop in PPO activity (by approximately 90 to $10 \%$ ) at high temperatures was likely due to the unfolding of the tertiary structure and denaturation of the enzyme. This result corroborates those of Todaro et al. (2011), who characterized PPO in eggplant and found a significant loss in activity at high temperatures.

For both of the cultivars tested, in both the pulp and seed, the PPO activity gradually decreased with increasing temperature, which indicates that high temperatures are not favorable to PPO activity and that the enzyme activity is higher between 25 and $30^{\circ} \mathrm{C}$.

\subsection{Determination of the preferential PPO substrate}

Both in the pulp and the seed and for both cultivars, the enzyme affinity was higher for catechin, with 11.93 U.mg protein ${ }^{-1}$ and 20.3 U.mg protein ${ }^{-1}$ in the pulp and 4.97 U.mg protein ${ }^{-1}$ and 11.69 U.mg protein $^{-1}$ in the seed for PH 16 and TSH 1188, respectively (Figure 5).

This result indicates that the enzyme did not present higher affinity for the compound present in higher concentration at the cocoa seed because in unfermented cocoa seeds in natura, $(-)$-epicatechin concentrations were twenty times higher than those of (+)-catechin (Kwik-Uribe, 2005).

In contrast, the concentration of total polyphenols decreased by approximately $70 \%$ during fermentation, and (-)-epicatechin decreased by $90 \%$ relative to its initial concentration (Efraim et al., 2011). The decrease in epicatechin can be explained by biological oxidation and/or monomer polymerization in addition to the epimerization of (-)-epicatechin into (-)-catechin due to the increase in temperature during fermentation (Payne et al., 2010). During the stages of cocoa processing for chocolate production, flavonoids go through a series of chemical reactions, such as oxidation, complexation and leaching, which together with other reactions, such as protein hydrolysis into amino acids and sugar hydrolysis, lead to the formation of aromatic compounds, significantly contributing to the formation of a desirable flavor and less bitterness and astringency (Cross, 1999).

It can therefore be stated that the drastic decrease of (-)-epicatechin during cocoa processing cannot be exclusively attributed to PPO activity but also to other, more important, mechanisms (see references above).

\subsection{Correlation between fermentation parameters and extractable enzyme activity}

The $\mathrm{pH}$ and temperature during fermentation and the optimal $\mathrm{pH}$ and temperature for PPO activity for the two tested cocoa cultivars are presented in Figures 6 and 7.

The highest PPO activity for the pulp of cultivar PH 16 was observed at $\mathrm{pH} 6.5$ (Figure 6a). However, the whole fermentation process of that cultivar took place at $\mathrm{pH} 4.5$. The fermentation $\mathrm{pH}$ only reached a value close to 6.0 after 5 days (120 hours) and then decreased again to approximately 4.5. Therefore, during the whole fermentation process of the pulp from cultivar $\mathrm{PH} 16$, the PPO activity was only $70 \%$ of the maximal activity. The highest PPO activity for the seed (6.5 U.mg protein ${ }^{-1}$ ) was observed at $\mathrm{pH} 5.8$ (Figure 6b). The $\mathrm{pH}$ at the beginning of seed fermentation was approximately 6.5 and slowly decreased to approximately 4.5. In this case, the enzyme activity was favored in the initial phases of fermentation, during the first 3 days ( 72 hours), and then decreased until it reached values close to $70 \%$ of its maximal activity. Therefore, although the PPO activity was lower in the seed than in the pulp, the activity of the seed PPO was favored by the medium $\mathrm{pH}$ during fermentation.

For cultivar TSH 1188, the pulp PPO presented higher activity (43.1 U.mg protein ${ }^{-1}$ ) at $\mathrm{pH}$ 6.6 (Figure 6c). The average $\mathrm{pH}$ value during fermentation for this cultivar was also approximately 4.5 , indicating that during its fermentation, PPO reached only $45 \%$ of its maximum activity ( $18 \mathrm{U} \cdot \mathrm{mg}$ protein ${ }^{-1}$ ). The initial 


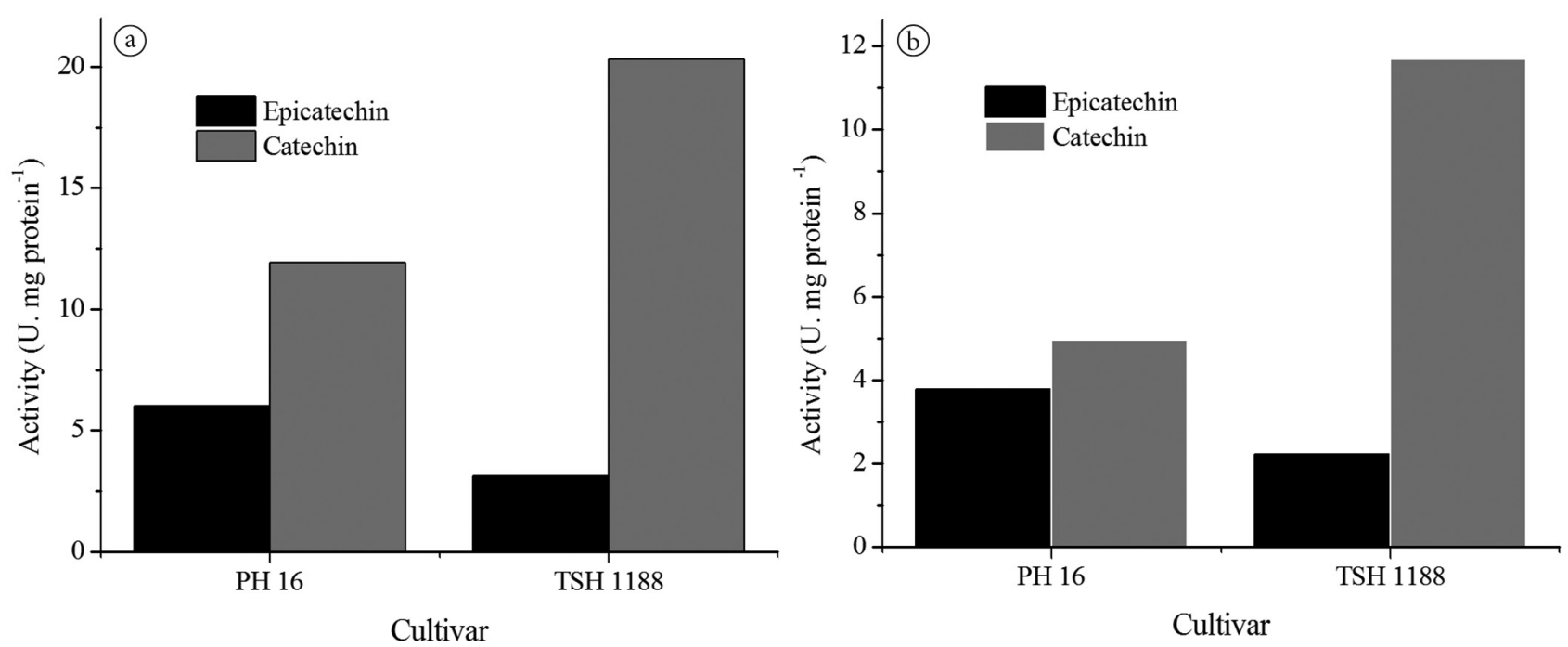

Figure 5. Determination of PPO activity for the preferential substrate: catechin and epicatechin. (a) Pulp; (b) Seed.
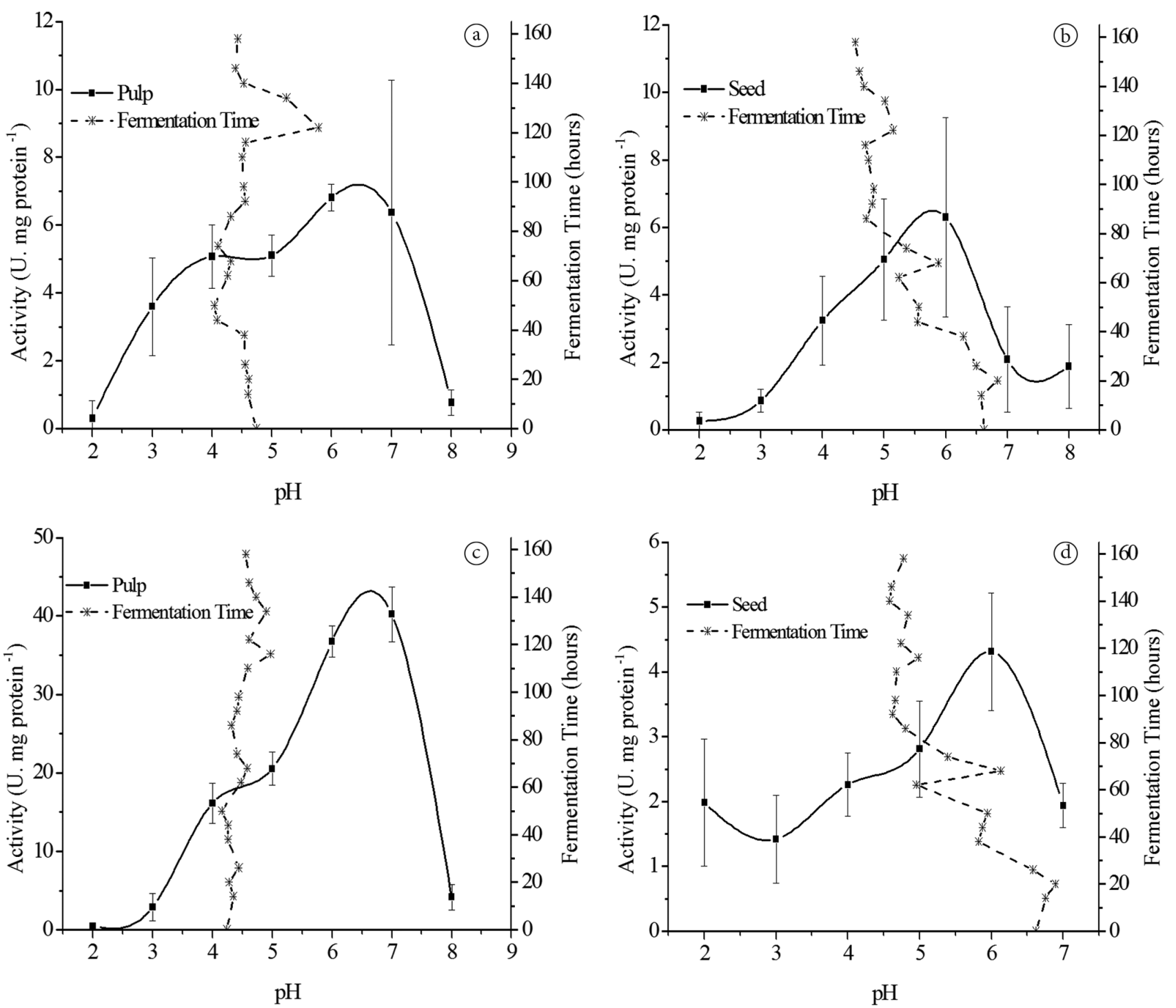

Figure 6. Fermentation parameters and optimal pH for PPO activity. (a) PH 16 - Pulp; (b) PH 16 - Seed; (c) TSH 1188 - Pulp; (d) TSH 1188 - Seed. 

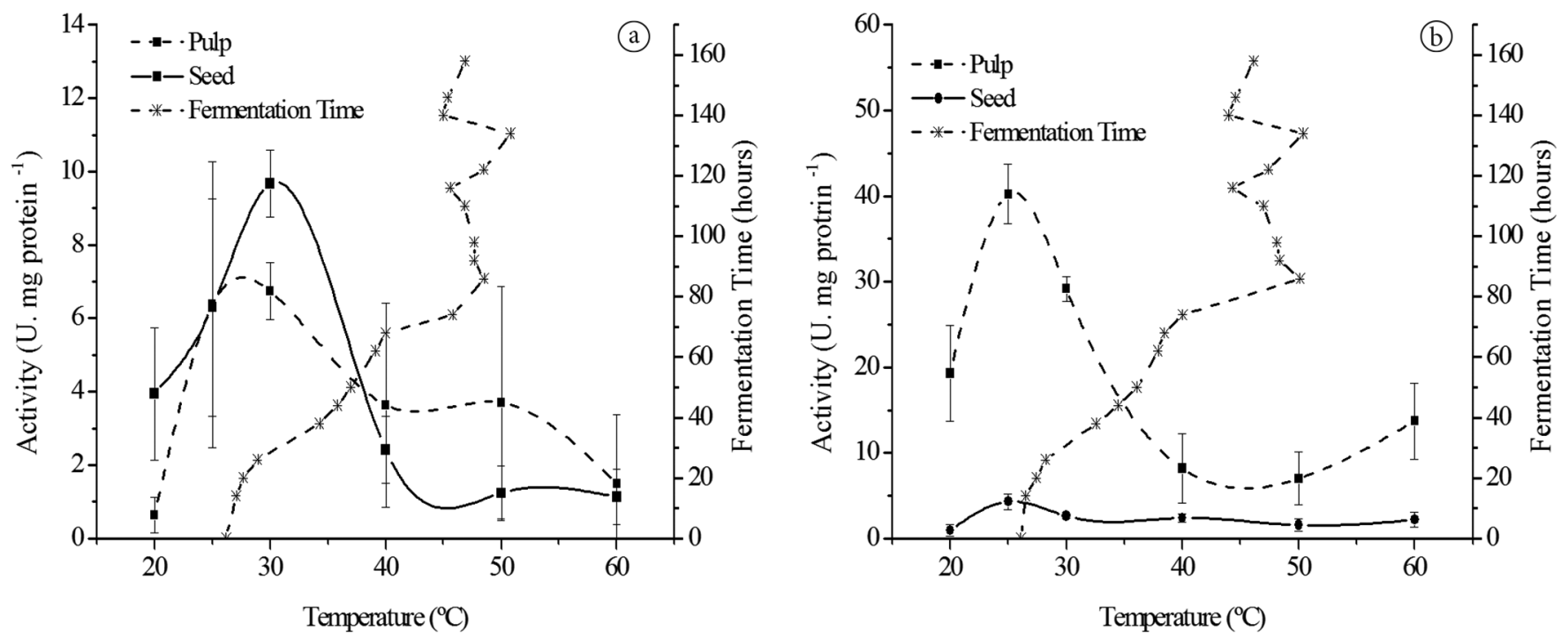

Figure 7. Fermentation parameters and PPO optimal temperature. (a) PH 16; (b) TSH-1188.

$\mathrm{pH}$ during seed fermentation was 6.6 and then decreased throughout fermentation until it stabilized at approximately $\mathrm{pH} 4.8$ (Figure 6d). Therefore, the fermentation $\mathrm{pH}$ remained at values resulting in higher PPO activity for the initial 72 hours. Following the initial 72 hours, the $\mathrm{pH}$ of the fermentation presented values at which the enzyme activity would be $70 \%$ of its maximum. It can therefore be concluded that the seed PPO activity is also favored by the $\mathrm{pH}$ at the initial fermentation stage (first 3 days) and that the differences in activity between pulp and seed are compensated during fermentation.

It should be highlighted that the $\mathrm{pH}$ found in the pulp at the beginning of fermentation (approximately $\mathrm{pH} 4.5$ ) for the two cultivars is in agreement with previous reports for fermented cocoa beans from the region of Bahia (Cruz et al., 2013). However, it has been reported that to obtain better results in nut quality, the fermentation $\mathrm{pH}$ should be between 5.0 and 5.5 (Amin et al., 2002). Better results for the tested cultivars can be obtained if measures are adopted to minimize precocious fermentation, which results from the breaking fruits in the field and during transport to the fermentation vats.

For cultivar PH 16, the highest PPO activity was observed at $30^{\circ} \mathrm{C}$ for the seed and at $27^{\circ} \mathrm{C}$ for the pulp (Figure $7 \mathrm{a}$ ). The temperature conditions observed during fermentation would only favor in both the pulp and the seed enzyme activity for the first 48 hours of fermentation. Following that period, with increasing fermentation temperature, the enzyme activity in the pulp initially decreased by $50 \%$, being reduced to $10 \%$ of the maximal activity at $45^{\circ} \mathrm{C}$. The enzyme activity in the seed would also be favored during the first 48 hours of fermentation. However, the decrease of PPO activity in pulp, with the temperature increase, was approximately $20 \%$. Although the enzyme activity of the seed was greater than the pulp, its resistance to high temperatures was weak, showing a drastic reduction after 48 hours.

For cultivar TSH 1188, the maximal enzyme activity was observed at $25^{\circ} \mathrm{C}$ for both the pulp and seed (Figure 7b). Therefore, as was observed for cultivar PH 16, the PPO activity was higher for the pulp only during the first 2 days of fermentation then decreased by approximately $60 \%$ when the temperature reached $35^{\circ} \mathrm{C}$. Although the PPO activity in the seed was much lower than that in the pulp, the seed PPO-activity decrease was minimal, with the activity remaining at similar values throughout the fermentation process.

The correlations presented show the specificity and differences between the enzymes from the pulp and seed from the tested cultivars and between the tested cocoa cultivars. This result is in accordance with Efraim et al. (2010), who tested temperature and $\mathrm{pH}$ during fermentation and observed differences in behavior between cocoa cultivars and among liquors, butter and chocolate.

\section{Conclusions}

The results of the present study suggest that during fermentation, specific criteria for each cocoa cultivar should be adopted, based on the cultivars' specificities and optimal $\mathrm{pH}$ and temperatures for $\mathrm{PPO}$, to prolong and increase $\mathrm{PPO}$ activity because the phenol oxidation performed by this enzyme in the seed is of great importance for the sensory characteristics of chocolate, such as bitterness and astringency.

Increasing the frequency and quantity of cocoa mass turnings at the beginning of fermentation may delay the increase of temperature and decrease of $\mathrm{pH}$, therefore prolonging $\mathrm{PPO}$ activity from the tested cultivars.

The control of $\mathrm{pH}$ and temperature will allow higher efficiency of the enzymes, prolonging the period of higher enzymatic activity during fermentation, and may contribute to the improvement of cocoa beans characteristics and consequently the quality of chocolate production.

\section{Ackowledgements}

The authors thank the Brazilian Federal Agency for the Support and Evaluation of Graduate Education (Coordenação de Aperfeiçoamento de Pessoal de Nível Superior/Brasil - Capes) 
for granting a graduate scholarship and the National Council for Scientific and Technological Development (Conselho Nacional de Desenvolvimento Científico e Tecnológico - CNPq) for financing the present study.

\section{References}

Amin, I., Jinap, S., Jamilah, B., Harikisna, K., \& Biehl, B. (2002). Analysis of vicilin (7S)-class globulin in cocoa cotyledons from various genetic origins. Journal of the Science of Food and Agriculture, 82(7), 28-732. http://dx.doi.org/10.1002/jsfa.1104.

Cross, E. (1999). Cocoa flavor development. The Manufacturing Confectioner, 79(2), 70-77.

Cruz, J. F. M., Leite, P. B., Soares, S. E., \& Bispo, E. S. (2013). Assessment of the fermentative process from different cocoa cultivars produced in Southern Bahia, Brazil. African Journal of Biotechnology, 12(33), 5218-5225. http://dx.doi.org/10.5897/AJB2013.12122.

Dogan, S., Turan, Y., Erturk, H., \& Arslan, O. (2005). Characterization and purification of polyphenol oxidase from Artichoke (Cynara scolymus L.). Journal of Agricultural and Food Chemistry, 53(3), 776-785. http://dx.doi.org/10.1021/jf049053g. PMid:15686433.

Efraim, P., Alves, A. B., \& Jardim, D. C. P. (2011). Polyphenols in cocoa and derivates: concentrations, variation factors and effects on health. Brazilian Journal of Food Technology, 14(3), 181-201. http://dx.doi. org/10.4260/BJFT2011140300023.

Efraim, P., Pezoa-García, N. H., Jardim, D. C. P., Nishikawa, A., Haddad, R., \& Eberlin, M. N. (2010). Influence of cocoa beans fermentation and drying on the polyphenol content and sensory acceptance. Ciência e Tecnologia Alimentos, 30(1), 142-150. http://dx.doi.org/10.1590/ S0101-20612010000500022.

Erzengin, M. (2009). Affinity, purification and characterization of polyphenol oxidase from Helianthus tuberosus L. Hacettepe. The Journal of Biological Chemistry, 37, 313-325.

Hansen, C. E., Del Olmo, M., \& Burri, C. (1998). Enzyme activities in cocoa beans during fermentation. Journal of the Science of Food and Agriculture, 77(2), 273-281. http://dx.doi.org/10.1002/(SICI)10970010(199806)77:2<273::AID-JSFA40>3.0.CO;2-M.

Horwitz, W. (Ed.). (2000). Official methods of analysis of the Association of Official Analytical Chemists (Vol. 2, 17th ed., pp. 20-24). Gaithersburg: AOAC.

Kwik-Uribe, C. (2005). Potential health benefits of cocoa flavanols. The Manufacturing Confectioner, 85(10), 43-49.

Lima, E. D. P. A., Pastore, G, M., Barbery, S, D, F., Garcia, N, H, P., Brito, E, S., Lima, C, A, A. (2001). Obtainment and use of polyphenol oxidase extracted from ripe pine (Annona squamosa L.) for the improvement of cocoa (Theobroma cacao L.) flavor. Revista Brasileira de Fruticultura, 23(3), 709-713. http://dx.doi.org/10.1590/S010029452001000300053.
Lineweaver, H., \& Burk, D. (1934). The determination of enzyme dissociation constants. Journal of the American Chemical Society, 56(3), 658-666. http://dx.doi.org/10.1021/ja01318a036.

Lowry, O. H., Rosebrough, N. J., Farr, A. L., \& Randall, R. J. (1951). Protein measurement with the Folin phenol reagent. The Journal of Biological Chemistry, 193(1), 265-275. PMid:14907713.

Misnawi, Jinap, S., Jamilah, B., \& Nazamid, S. (2003). Sensory properties of cocoa liquor as affected by polyphenol concentration and duration of roasting. Journal of Food Quality and Preference, 15(5), 403-409. http://dx.doi.org/10.1016/S0950-3293(03)00097-1.

Misnawi, Jinap, S., Nazamid, S., Jamilah, B. (2002) Activation of remaining key enzymes in dried under-fermented cocoa beans and its effect on aroma precursor formation. Food Chemistry, 78, 407-417.

Oktay, M., Küfreviolu, I., Kocaçalişkan, I., \& Şaklrolu, H. (1995). Polyphenoloxidase from Amasya apple. Journal of Food Science, 60(3), 494-505. http://dx.doi.org/10.1111/j.1365-2621.1995.tb09810.x.

Payne, M. J., Hurst, W. J., Miller, K. B., Rank, C., \& Stuart, D. A. (2010). Impact of Fermentation, drying, roasting, and dutch processing on epicatechin and catechin content of Cacao Beans and cocoa ingredients. Journal of Agricultural and Food Chemistry, 58(19), 10518-10527. http://dx.doi.org/10.1021/jf102391q. PMid:20843086.

Perone, C. A. S., Queiroz, A. S., Dalosso, V. M., \& Moreira, M. E. M. (2007). Partial purification and kinetic characterization of polyphenol oxidase in banana nanica (Musa acuminata). Revista do Instituto de Ciências da Saúde, 25, 239-246.

Reeves, S. G., McDowell, I., Behn, K., \& Dench, J. (1988). Biochemical studies of Cocoa Bean o-diphenol $\mathrm{O} 2$ oxidoreductase (catechol oxidase). Food Chemistry, 29(3), 209-219. http://dx.doi.org/10.1016/03088146(88)90134-3.

Robinson, D. S., \& Eskin, N. A. M. (1991a). Oxidative Enzymes in Foods (Chap 1, p. 1-47). London: Elsevier Applied Science.

Robinson, D. S., \& Eskin, N. A. M. (1991b). Oxidative Enzymes in Foods (Chap, 6, p. 217-273). London: Elsevier Applied Science.

Todaro, A., Cavallaro, R., Argento, S., Branca, F., \& Spagna, G. (2011). Study and characterization of polyphenol oxidase from Eggplant (Solanum melongena L.). Journal of Agricultural and Food Chemistry, 59(20), 11244-11248. http://dx.doi.org/10.1021/jf201862q. PMid:21942648.

Toralles, R. P., Vendruscolo, J. L., Vendruscolo, C. T., Del Pino, F. A. B., \& Antunes, P. L. (2010). Control of activity of polyphenol oxidase in peach through the interaction between $\mathrm{pH}$, temperature and ascorbic acid concentration. Brazilian Journal of Food Technology, 13(2), 120-127. http://dx.doi.org/10.4260/BJFT2010130200016.

Yusep, I., Jinap, S., Jamilah, B., \& Nazamid, S. (2002). Influence of carboxypeptidases on free aminoacid, peptide and methylpyrazine contents of under-fermented cocoa beans. Journal of the Science of Food and Agriculture, 82(13), 1584-1592. http://dx.doi.org/10.1002/ jsfa.1232. 